\title{
KAJIAN INTEGRATIF SITUS PRASEJARAH DI KAWASAN MANGKULIRANG, KUTAI TIMUR \\ (Integrative Study of Prehistoric Site in Mangkulirang Region, East Kutai)
}

\section{Nasruddin}

Pusat Penelitian Arkeologi Nasional Jl. Raya Condet Pejaten No.4, Pasar Minggu, Jakarta.

Telp. (021) 7988171 e-mail: undink.anaugi@gmail.com

\section{INFO ARTIKEL}

\section{Histori artikel}

Diterima: 20 Juli 2016

Direvisi: 10 Agustus 2016

Disetujui: 14 Oktober 2016

\section{Keywords:}

potential prehistoric archaeology, research, and

conservation in an integrated manner.

\section{Kata kunci: \\ potensi arkeologi prasejarah, penelitian, dan \\ pelestarian secara terpadu.}

\begin{abstract}
Studies on karst is a study that can be done holistically, because in the karst region there are various potentials such as; prehistoric archaeological remains which are quite old, there are groups of people who have local knowledge seekers swallow nest, traditional agricultural activities and the utilization of the site of the settlement (settlement area), as well as habits embodied in traditions and art. Through archaeological approach to spatial (spatial archeology), the archaeological research in East Kutai Karst, not only reveal the spatial and temporal aspects alone, but as a whole want to explain culturally and physically; synchronic and diachronic this region inhabited by humans. Mangkulirang karst area is so vast traffic would require a study to obtain an explanation; subsistence, technology and the ancient environment, as well as the adaptation of the system that have become extinct. Cave sites and niches in the Mangkulirang a valuable contribution to the knowledge of the history and prehistory of cultural processes. Any kind of potential above require management in the context of synergy, participation and shared responsibility with the local authorities, cross-institutional and community organizations, as well as cross-sectoral and multi-disciplinary to minimize conflicts of the various interests in the karst region in the management and preservation of cultural heritage Indonesia.
\end{abstract}

\begin{abstract}
ABSTRAK
Kajian tentang karst adalah kajian yang dapat dilakukan secara holistik, karena di dalam kawasan karst terdapat berbagai potensi seperti; tinggalan arkeologis prasejarah yang cukup tua, terdapat kelompok-kelompok masyarakat yang memiliki kearifan lokal, para pencari sarang walet, aktivitas pertanian tradisional dan pemanfaatan menjadi lokasi pemukiman, serta kebiasaan-kebiasaan yang diwujudkan dalam bentuk tradisi dan kesenian. Melalui pendekatan arkeologi keruangan, maka penelitian arkeologi di Karst Kutai Timur, tidak hanya mengungkapkan aspek spasial dan temporal saja, tetapi secara utuh ingin menjelaskan secara kultural maupun fisikal; sinkronik maupun diakronik kawasan ini dihuni manusia. Kawasan karst Mangkulirang yang begitu luas tentunya memerlukan lintas kajian untuk memperoleh penjelasan; subsistensi, teknologi dan lingkungan purba, serta sistem adaptasi yang telah punah. Situs gua dan ceruk di kawasan Mangkulirang dapat memberikan kontribusi berharga terhadap pengetahuan sejarah dan proses budaya prasejarahnya. Segala jenis potensi di atas memerlukan pengelolaan dalam rangka sinergitas, peran serta dan tanggung jawab bersama dengan pemerintah daerah, lintas kelembagaan dan organisasi masyarakat, maupun lintas sektoral dan multi disiplin untuk meminimalisir benturan atas berbagai kepentingan di kawasan karst dalam rangka pengelolaan dan pelestarian cagar budaya Indonesia.
\end{abstract}

PENDAHULUAN

Kabupaten Kutai Timur
merupakan salah satu wilayah hasil
pemekaran dari Kabupaten Kutai
dibentuk berdasarkan Undang
Undang No. 47 tahun 1999. Batas-

batas Kabupaten Kutai Timur adalah di sebelah utara berbatasan dengan Kabupaten Bulungan, sebelah timur dengan Selat Makassar, sebelah Selatan dan barat berbatasan dengan Kabupaten Kutai Kartanegara. Wilayah Kutai Timur terletak pada 
posisi koordinat antara $115^{\circ} 56^{\prime} 26^{\prime \prime}$ $118^{\circ} 58^{\prime} 19^{\prime \prime}$ BT dan $1^{\circ} 17^{\prime} 1^{\prime \prime}$ LS - $1^{\circ} 52^{\prime}$ 39" (Bappeda, 2007).

\begin{abstract}
Bukan berita tetapi menjadi fakta, lingkungan karst dengan segala potensinya dieksplorasi secara berlebihan untuk berbagai kepentingan, sehingga sejumlah kawasan karst terancam keberadaannya. Eksplorasi yang terjadi itu, bisa berupa kegiatan pertambangan, perambahan hutan (illegal loging), perkebunan dan pemanfaatan pemukiman oleh masyarakat pendatang.
\end{abstract}

Kondisi ini juga mulai merambah memasuki kawasan karst Mangkulirang, bahkan perambahan hutan telah terjadi sejak lama dan eksplorasi tambang batu bara juga semakin mendekati kawasan situs gua prasejarah Mangkulirang. Faktafakta lapangan ini perlu segera diatasi untuk mencegah konflik kepentingan terhadap pengelolaannya.

Nama Mangkulirang adalah dua nama wilayah yaitu "Mangkalihat" dan "Sangkulirang" yang kemudian digabung menjadi satu istilah yang dipopulerkan oleh masyarakat setempat, terutama oleh para masyarakat pemburu sarang burung walet. Terkait dengan berbagai potensi yang dimiliki karst Mangkulirang maka dapat diidentifikasi sejumlah persoalan besar yang mengancam punahnya berbagai potensi tersebut. Dapat dikemukakan sejumlah masalah yang dihadapi kawasan ini meliputi:

1. Kegiatan penebangan hutan yang intensif dan pengambilan sarang burung wallet yang tidak sesuai dengan kaidah-kaidah pemanfaatan yang berkelanjutan

2. Kegiatan land-clearing untuk perkebunan $\mathrm{HTI}$ atau ladang sebagai sumber kebakaran hutan. Munculnya perkebunan skala besar yang bisa mempengaruhi keseimbangan hayati

3. Kegiatan aktifitas pertambangan batu bara rakyat yang berpotensi merusak geomorfologi karst dan lapisan penutup vegetasi

4. Potensi galian dan bahan baku semen yang telah diincar oleh sejumlah perusahaan besar

5. Rencana pembangunan jalan trans timur Kalimantan yang membelah kawasan hutan karst (Batu PutihPerondongan)

6. Tidak diakuinya hak masyarakat adat atas sumberdaya alam yang mereka miliki, sehingga seringkali terjadi pengambilalihan penguasaan komunitas adat atas kawasan atau SDA tertentu oleh pemerintah atau badan usaha swasta

7. Hukum dan kelembagaan adat tidak lagi berfungsi efektif dalam menyelesaikan konflik-konflik SDA, sementara hukum negara juga tidak mampu menjangkau persoalan tersebut

8. Kawasan karst ini berada di dua kabupaten, yaitu Kutai Timur dan Berau, yang hingga saat ini belum adanya pengelolaan yang mencakup perlindungan lingkungan karst dan warisan budaya (situs gua prasejarah), sehinggadiperlukan koordinasi yang sinergis untuk kepentingan pengelolaan sumberdaya alam dan warisan budaya

9. Perlunya pemetaan secara terpaduantar lintas sektoral dengan memetakan batas-batas wilayah dan zona pelindungan, pemanfaatan, dan pengembangan berdasarkan Undang Undang Cagar Budaya No.11 tahun 2010. 


\section{PEMBAHASAN \\ Distribusi Tapak dan Seni Purba}

Kalimantan merupakan pulau terbesar yang ada di wilayah negara kepulauan Indonesia. Dengan luas yang hampir meliputi lima kali luas Pulau Jawa, Kalimantan merupakan suatu wilayah yang mempunyai potensi besar dalam mengungkap misteri sejarah yang pernah terjadi di masa lampau, terutama berkaitan dengan tinggalan gua-gua hunian pada masa prasejarah yang secara alamiah masih terlindungi di dalam hutan lebat pada daerah-daerah pegunungan kapur.

Situs prasejarah yang serupa seperti Gua Niah yang ditemukan di bagian utara Kalimantan yang menjadi wilayah negara bagian Serawak; sementara beberapa situs gua prasejarah lainnya ditemukan di negara bagian Sabah yang terletak di Taman Nasional Gunung Mulu; sedangkan di Kalimantan Barat berhasil didata sejumlah gua-gua hunian prasejarah, yaitu antara lain Situs Batu Cap, Gua Tengkayu, Gua Batu Bakil, dan Batu Kadok (Bellwood, 1985: 78-80).

Dari hasil penelitian yang dilakukan oleh Pusat Penelitian Arkeologi Nasional dan Balai Arkeologi Banjarmasin juga telah banyak diketahui bahwa di wilayah Kalimantan Selatan terdapat beberapa situs gua prasejarah yang sangat potensial, diantaranya adalah Gua Babi dan Gua Tengkorak (Sugiyanto, 2005: 12-15).

Apabila diperhatikan keseluruhan hasil investigasi berdasarkan observasi dan penggalian pada lubang uji (test pit) di Gua Tengkorak, maka hal yang menarik didiskusikan kaitannya dengan konteks temuan permukaan yang terdiri dari pecahan tembikar, wadah tempayan yang terletak di sela-sela dinding gua dan telah terbalut dengan travertin, sejumlah gigi manusia serta adanya gambar cap tangan yang tertera di dinding dan langit-langit gua, walau secara kuantitas jauh lebih sedikit dibanding dengan Gua Tewet. Dan kemudian membandingkan temuan-temuan tersebut dengan temuan yang berhasil dihimpun melalui hasil penggalian:

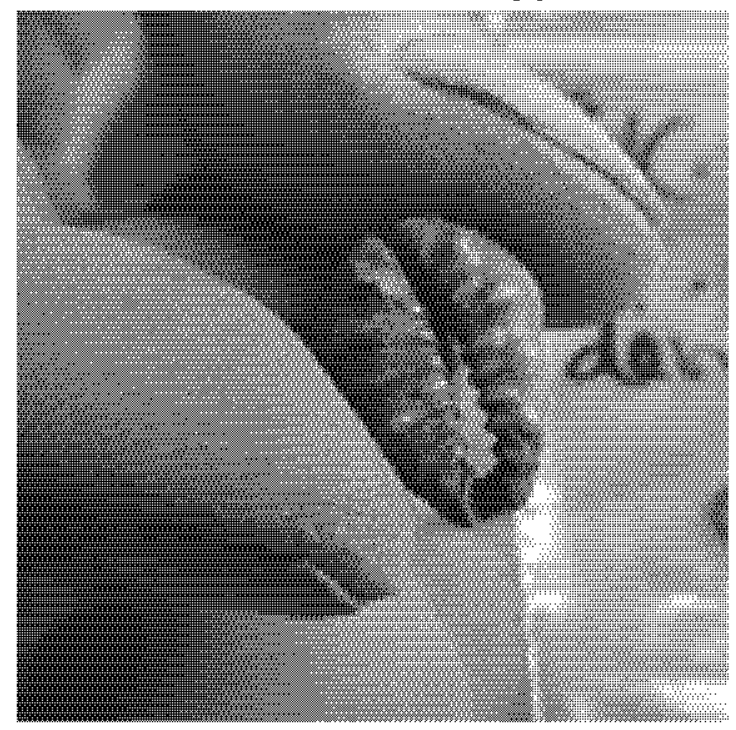

Gambar 1. Artefak kerang yang menjadi salah satu ciri temuan di situs gua-gua peg. Marang, Kaltim (dokumentasi Nasruddin)

Dari hasil penelitian yang dilakukan oleh Pusat Penelitian Arkeologi Nasional dan Balai Arkeologi Banjarmasin juga telah banyak diketahui bahwa di wilayah Kalimantan Selatan terdapat beberapa situs gua prasejarah yang sangat potensial, diantaranya adalah Gua Babi dan Gua Tengkorak (Sugiyanto, 2005: 12-15).

$\begin{array}{cc}\text { Apabila } & \text { diperhatikan } \\ \text { keseluruhan hasil investigasi }\end{array}$
berdasarkan observasi dan penggalian pada lubang uji (test pit) di Gua Tengkorak, maka hal yang menarik didiskusikan kaitannya dengan konteks temuan permukaan yang terdiri dari pecahan tembikar, wadah tempayan yang terletak di sela-sela dinding gua dan telah terbalut dengan travertin, sejumlah gigi manusia serta adanya gambar cap tangan yang tertera di dinding dan langit-langit gua, walau 
secara kuantitas jauh lebih sedikit dibanding dengan Gua Tewet. Dan kemudian membandingkan temuantemuan tersebut dengan temuan yang berhasil dihimpun melalui hasil penggalian:

Pecahan tembikar berhias, merupakan bukti adanya jejak hunian di situs-situs gua di kawasan karst Mangkulirang, sekaligus menjadi data migrasi awal penutur bahasa Austronesiayang setingkat dengan periode Dayak Tua, hal ini dapat dibaca terutama gejala temuan permukaan berupa pecahan tembikar, tempayan dengan ukuran periuk dan beberapa gigi manusia. Selain itu, ada pula data lain dari temuan test pit pada awal kedalaman, yaitu antara $5-10 \mathrm{~cm}$. Data ini menjelaskan bahwa Gua Tengkorak masih digunakan pada masa kemudian di periode masehi ketika terjadi kontak dengan dunia luar, mungkin melalui hubungan perdagangan. Asumsi ini terutama diperkuat oleh adanya temuan pecahan keramik Cina pada kotak ekskavasi di Liang Jon dengan konteks stratigrafi yang sama dengan temuan pecahan tembikar.

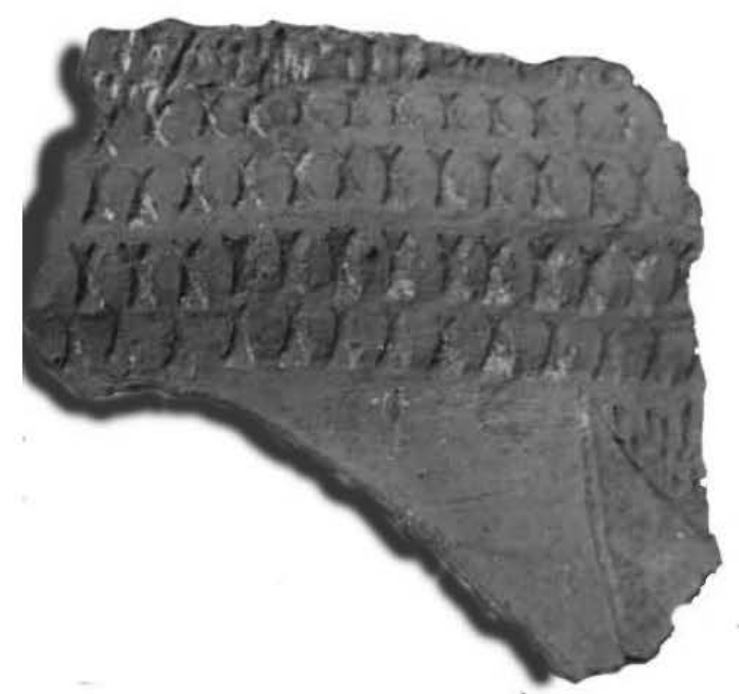

Gambar 2. Temuan permukaan berupa pecahan tembikar berhias (dokumentasi Nasruddin)
Artefak Serpih, sangat jelas bahwa situs Gua Tengkorakadalah situs hunian masa prasejarah yang cukup tua, setidaknya dapat diperkirakan pada periode budaya setingkat dengan era mesolitik dan mungkin berlangsung hingga awal neolitik. Bukti kuat yang memperjelas tingkat budaya mereka adalah mesolitik yang diperlihatkan oleh penggunaan alat-alat batu serpih sebagai pendukung utama kehidupan hunian gua. Sisa-sisa tulang binatang dengan berbagai jenis hewan, dan tumpukan moluska menggambarkan bentuk dan pola makan, bahwa sumber makanannya sangat ditentukan oleh lingkungan alam dengan mata pencarian adalah perburuan.

Gambar-gambar gua yang tertera di Gua Tewet khususnya, berupa; tanda tangan, garis-garis illustrasi yang membentuk satu pola cerita, dan gambar-gambar figur manusia dan binatang menjadi satu kesatuan dekorasi dalam dinding gua yang sangat mengagumkan. Ketika menatap, menghitung dan merekam gambar-gambar itu, seolah mengutarakan sesuatu. Gambargambar itu menjadi bukti bahwa mereka dahulu telah memiliki kemampuan melukis dengan peralatan seadanya, tetapi melahirkan suatu karya seni yang memiliki dimensi dan perspektif yang perlu diterjemahkan.

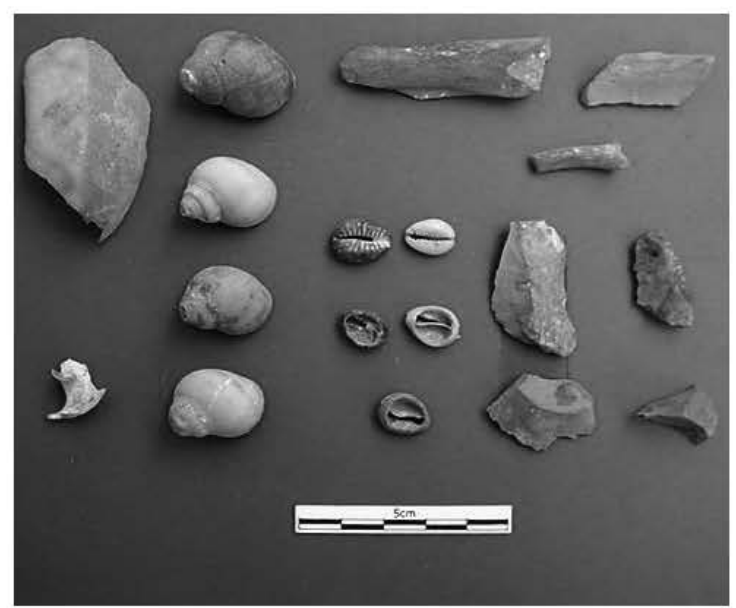

Gambar 3. Himpunan temuan artefak sebagai bukti aktivitas manusia dalam gua di situs gua di Kalimantan Timur (dokumentasi Nasuddin) 
Situs Gua Tengkorak hanyalah salah satu gua diantara sekian banyak gua di Kawasan Pegunungan Marang yang dapat dipastikan memiliki indikasi arkeologis, sebut saja situs gua Jon, dan llas Kairim juga ditemukan sebaran artefak batu berupa serpih di permukaan atau di lantai gua sebagai bukti dan jejak hunian prasejarah yang dapat dianalisis lebih lanjut.

Berdasarkan hasil-hasil penelitian di atas dapat diketahui bahwa gua dan ceruk di kawasan karst Mangkulirang terbukti pernah digunakan manusia masa lampau sebagai tempat tinggal sementara atau menetap. Dipilihnya gua sebagai tempat tinggal manusia prasejarah dapat dibuktikan dengan ditemukannya berbagai situs prasejarah melalui bekas telapak tangan atau garca yang tertera pada dinding gua, maupun artefak litik yang terpendam dalam lapisan tanah gua melalui ekskavasi yang sistematis.

Peran pemerintah daerah sangat dibutuhkan untuk bersama-sama para arkeolog dan pemerhati lingkungan untuk segera melakukan proteksi terhadap warisan budaya gua dan lingkungannya. Terutama memberikan bantuan dan dukungan kerjasama penelitian yang seluas-luasnya, karena situs gua-gua ini, selain sebagai bukti hunian prasejarah wilayah Kalimantan pada masa lampau, sekaligus memiliki nilai penting sebagai warisan budaya yang perlu diteliti dan dilestarikan sebagai cagar budaya dunia.

Dari berbagai data temuan arkeologis tersebut menunjukkan bahwa ternyata Pulau Kalimatan tidak hanya kaya dengan sumberdaya alam dan tambangnya, tetapi juga kaya akan sumberdaya arkeologi berupa situs-situs gua hunian prasejarah yang mempunyai gambar cadas purba di dalamnya. Peninggalan imaji-imaji purba yang terdapat di pegunungan karst Marang, Kecamatan Bengalon dan pegunungan karst di sekitar Kecamatan Sangkulirang, Kabupaten Kutai Timur, Kalimantan Timur merupakan data penting bagi perkembangan penelitian arkeologi di Indonesia, terutama dalam kaitannya mengungkap sejarah kehidupan masa lalu di wilayah ini.

Awal penemuan garca purba di Kutai Timur bermula dari ekspedisi yang dilakukan di daerah hulu Sungai Kapuas, Kalimantan Barat. Kemudian kegiatan penelitian itu dipindahkan ke arah timur, yaitu di daerah Kalimantan Timur. Di pegunungan karst di sekitar Desa Pengadan tim ini kembali menemukan beberapa gua bergambar yang cukup potensial (diantaranya Gua Mardua). Selain itu tim juga berhasil menemukan gua-gua bergambar lainnya di pegunungan karst Marang, Kecamatan Bengalon, Kabupaten Kutai Timur, Kalimantan Timur. Sampai saat ini sudah tercatat sekitar 30 gua bergambar yang berhasil ditemukan di kedua pegunungan karst tersebut, dengan jenis dan ragam gambar yang sangat variatif (Prasetyo, 1997: 44-51).

Hasil eksplorasi yang dilakukan oleh Credo-CNRS, Maison Asie Pacifique, Marseille France dan kerjasama Puslit Arkenas (Pusarnas) di Kalimantan Timur (2003-2004) berhasil mengungkapkan berbagai jejak gua-gua hunian prasejarah yang terdapat di daerah Pegunungan Kapur Tanjung Mangkalihat dan gua-gua di Pegunungan Sangkulirang (Marang) (Nasruddin, 2004). Pada umumnya temuan gua-gua hunian prasejarah di wilayah ini (Kutai Timur) mempunyai jejak-jejak tinggalan prasejarah berupa artefak batu, manusia dan imaji seni (garca). Beberapa diantaranya dapat dikemukakan secara deskriptif yaitu meliputi 


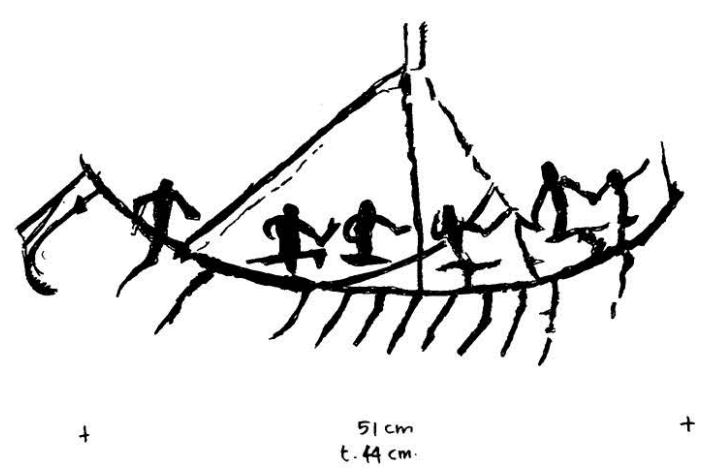

Gambar 4. Imaji perahu dengan awaknya, terdapat di gua Mardua. (dokumentasi Pindi Setiawan)

\section{Gua Mardua}

Gua Mardua merupakan gua tebing yang terletak pada dinding perbukitan karst (gunung batu) dengan ketinggian sekitar 50 meter dari permukaan tanah atau 130 meter dari permukaan laut (dpal). Untuk mencapai gua tersebut harus mendaki jalan setapak yang cukup terjal (sekitar $80^{\circ}$ ) dan menembus hutan semak-belukar. Secara morfologis, Gua Mardua mempunyai bentuk memanjang dengan ukuran lebar halaman tiga meter dan panjang sekitar 42 meter serta mempunyai dua lorong ke arah dalam.

Imaji-imaji seni yang terdapat di Gua Mardua berupa gambar-gambar telapak tangan berwarna merah ( 9 buah), gambar pohon (?) berwarna merah (1 buah), gambar-gambar hewan (hewan melata dan laba-laba) berwarna merah 4 buah. Seluruh gambar-gambar berwarna merah (dibuat dari bahan pewarna hematit) ini terletak di dinding pintu gua; berjajar dari utara- selatan (menghadap ke timur) dengan tinggi antara 4-5 meter dari lantai gua. Selain itu, di gua ini juga ditemukan sekitar 20 jenis gambar perahu (Austronesia ?) dan perahu uap dengan warna hitam (dari bahan arang) yang dilukis hanya setinggi manusia, sehingga sudah banyak yang tertimpa coretan baru dari para pengunjung.

\section{Ceruk Lungun}

Lokasi Ceruk Lungun terletak sekitar 5 km dari Desa Pengadan dan masuk ke arah baratlaut sekitar 2 km. Gua Lungun merupakan gua payung (rockshelter) yang terletak pada dinding perbukitan karst dengan ketinggian sekitar 40 meter dari permukaan tanah atau 130 meter dari permukaan laut (dpal).

Jejak tinggalan arkeologis yang terdapat di Gua Lungun berupa peti kubur yang terbuat dari kayu ulin. Di situs ini ditemukan 4 buah lungun yang sudah dalam kondisi rusak dan berantakan. Lungun atau peti kubur ini terdiri dari wadah dan tutup. Wadah tersebut dibuat dari batang gelondongan kayu utuk yang dilubangi di bagian tengahnya sehingga membentuk segiempat. Lungun mempunyai ukuran rata-rata panjang $237 \mathrm{~cm}$, lebar $20 \mathrm{~cm}$ dan tebal $2 \mathrm{~cm}$, sedangkan tutupnya mempunyai ukuran panjang $325 \mathrm{~cm}$, lebar $36 \mathrm{~cm}$ dan tinggi $20 \mathrm{~cm}$. Pada masing-masing sudutnya, tutup lungun tersebut mempunyai hiasan berbentuk tonjolan menyerupai tanduk kerbau. LungunLungun tersebut ditopang oleh 2 tiang kayu dengan ukuran tinggi antara 120 $150 \mathrm{~cm}$ dan diameter $20 \mathrm{~cm}$. Salah satu tiang kayu penyangga lungun tersebut mempunyai hiasan menarik; yaitu berupa dua buah tonjolan payudara wanita. Tanda tiang semacam ini mencerminkan bahwa lungun tersebut merupakan penguburan dari seorang wanita (Prasetyo, et. al., 1995). Selain itu, dari penelitian yang dilakukan oleh Balai Arkeologi Banjarmasin di gua ini juga berhasil mendapatkan sejumlah temuan yang dikumpulkan melalui pembuatan sebuah lubang uji (test pit), yaitu antara lain berupa fragmen gerabah, fragmen tulang binatang, fragmen cangkang kerang, 
dan beberapa artefak litik (Nasruddin, 2003: 20-25).

\section{Gua Tewet}

Gua ini terletak di kawasan lereng pegunungan karst yang terdapat di tepian Sungai Jelai, berada pada ketinggian sekitar 200 meter dari permukaan sungai. Gua Tewet ini menghadap ke arah barat dengan kondisi langit-langit gua yang tidak terlalu tinggi. Pada langit-langit gua terdapat gambar berupa: cap tangan dengan beberapa variasi tatonya, rusa, kura-kura dan sejenis insekta, serta lukisan tentang manusia duduk bersila di atas air yang diapit oleh gambar dua cap tangan (negative hand stencils). Semua gambar cap tangan dibuat dengan teknik stensil dan menggunakan warna merah, sedang gambar binatang dan manusia menggunakan warna hitam. Jumlah cap tangan di Gua Tewet ini ada sekitar 179 buah (Nasruddin, 2003:31-33).

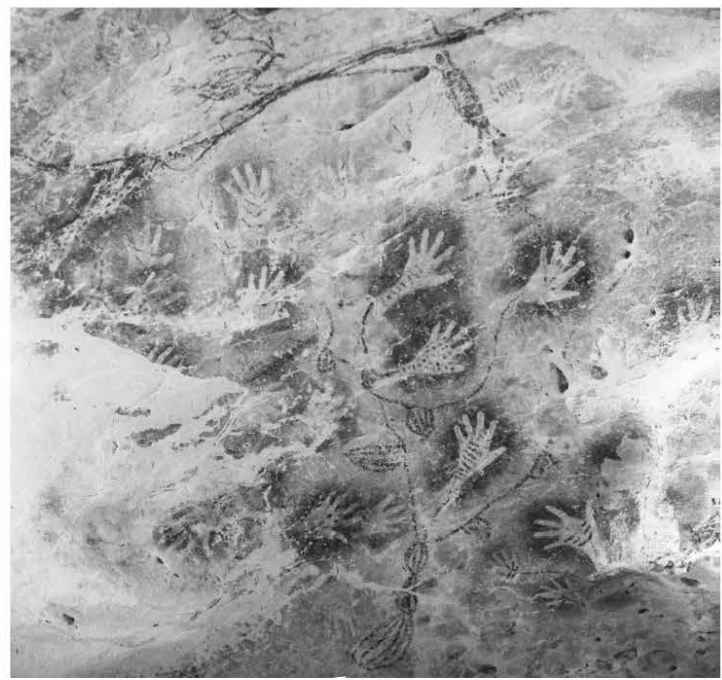

Gambar 5. Gambar-gambar telapak tangan yang sangat variatif di Liang Tewet (dokumentasi Puslit Arkenas)

\section{Gua Jon}

Gua Jon ini merupakan sebuah liang atau ceruk peneduh (rock shelter) yang terletak di bagian hulu Sungai Metam, Ekskavasi pada Gua Jon ini dilakukan dengan dua tahap, yaitu tahap I pada tahun 2003 dan tahap II pada tahun 2005. Jejak tinggalan arkeologis yang terdapat di Gua Jon antara lain berupa rangka manusia dan ratusan alat litik dengan berbagai tipe, fragmen tulang-tulang binatang dan sejumlah fragmen tembikar.

\section{Gua Tengkorak}

Dari hasil penelitian melalui pembuatan tiga buah kotak lubang uji pada tahun 2003 membuktikan bahwa gua ini mempunyai indikator sebagai tempat hunian manusia pada masa lalu. Bukti-bukti temuan tersebut antara lain berupa beberapa artefak litik, fragmen tembikar (gerabah), gigi manusia, tulang-tulang binatang, kerang dan arang (abu bekas pembakaran) yang didapatkan pada kedalaman sekitar satu meter dari permukaan tanah. Bukti temuan sisa-sisa kehidupan manusia serta adanya garca di Gua Tengkorak menunjukkan bahwa gua tersebut pernah menjadi tempat bermukim manusia pada masa yang lalu. Dari sisa-sisa sampah makanan seperti tulang hewan, dan tumpukan moluska menggambarkan pola makan kelompok pemburu-peramu. Goa ini juga dihuni atau menjadi tempat kubur manusia pasca prasejarah.

Selain itu, jejak tinggalan arkeologis yang terdapat di Gua Tengkorak berupa lukisan cap tangan yang terdapat di dinding dan langitlangit gua. Kondisi imaji-imaji di gua Tengkorak pada umumnya berupa tera tangan yang sudah sangat tipis dan rusak.

\section{Gua Kebobo}

Situs Gua Keboboh merupakan salah satu kompleks gua-gua dan ceruk alam yang ada di deretan Pegunungan Marang di Desa Tepian langsat, Kecamatan Bengalon, Kabupaten Kutai Timur. Di kompleks ini sedikitnya 
telah ditemukan dua buah gua yang mengandung indikator arkeologis (Gua Kebobo-1 dan Kebobo-2), sedangkan satu gua lainnya (Gua Kebobo-3) sudah dimanfaatkan sebagai lokasi ternak sarang burung walet. Lokasi Gua Kebobo-1 terletak pada dinding perbukitan Marang dengan kemiringan hampir $80^{\circ}$ dan berada pada ketinggian antara 30-40 meter dari permukaan air Sungai Marang.

Berdasarkan hasil penelitian yang dilakukan di Situs Gua Kebobo-1 dan Kebobo-2 pada tahun 2004, membuktikan bahwa kedua gua ini pernah dipakai sebagai hunian dan aktivitas manusia pada masa lalu (prasejarah). Melalui pembuatan empat buah kotak lubang uji (test pit) dengan kedalaman rata-rata hampir satu meter yang dilakukan dalam penelitian tersebut telah didapatkan berbagai temuan yang sangat melimpah di situs ini. Jejak tinggalan arkeologis tersebut antara lain berupa fragmen tembikar (hias dan polos), fragmen tulang dan gigi manusia/hewan, manik-manik dan perhiasan kerang, alat serpih-bilah (dari batu api), hematit, fragmen cangkang kerang, fragmen buah/biji damar, dan sisa-sisa bekas pembakaran (arang dan tanah terbakar) (Jatmiko, et. al., 2004).

\section{Gua Batu Aji}

Gua Batu Aji merupakan salah satu lokasi dari situs gua-gua dan ceruk alam yang terdapat di Pegunungan Marang di Desa Tepian langsat, Kecamatan Bengalon, Kabupaten Kutai Timur. Hasil pengamatan yang pernah dilakukan memperlihatkan indikator temuan yang cukup banyak berupa fragmen tembikar (gerabah), serpihserpih litik (dari batu api), cangkang kerang, fragmen tulang-tulang fauna dan jejak-jejak bekas pembakaran (arang dan tanah terbakar).
Selain temuan-temuan tersebut, dalam ekskavasi berhasil menemukan sisa-sisa penguburan berupa tiga buah rangka manusia. Temuan rangka manusia yang didapatkan dalam penggalian di situs ini merupakan data yang sangat penting untuk mengungkap kehidupan masa lalu, terutama berkaitan dengan manusia pendukung budaya di gua ini.

\section{Gua Liang Karim}

Gambar-gambar yang terdapat di Liang Karim mengandung imaji yang sangat istimewa, yaitu berupa gambar sarang lebah dan tapir. Sarang lebah sangat umum digambar pada cadascadas di dunia, hal ini menggambarkan mata-pencaharian meramu hasil hutan. Di Indonesia imaji sarang lebah hanya ditemukan di situs Liang Karim. Imaji sarang lebah dan tapir digambarkan cukup besar, memenuhi seluruh ruang gambarnya yang terletak 2,5 meter di atas lantai ceruk. Binatang tapir (Tapirus indicus) sudah punah pada sekitar 6.000 tahun lalu di Kalimantan, sehingga gambar-gambar yang terdapat di gua ini merupakan bukti bahwa pernah ada tapir di kawasan ini.

\section{Distribusi situs yang padat}

Selain gua-gua yang sudah diuraikan tersebut, di kompleks Batu Gergaji masih terdapat sejumlah gua-gua lainnya, seperti Kompleks Gua Karim, Gua Ujan, dan Gua Pindi. Gua Pindi tampaknya pernah menjadi gua yang penting, karena posisinya langsung menghadap sungai. Lantainya juga tampak rata dan kering, sayangnya dewasa ini lantai goa hampir seluruhnya tertimbun reruntuhan. Gambar yang tersisa hanyalah antropomorfik. Imaji ini hanya terlihat bagian atasnya saja, sedang bagian bawahnya tertutup tanah dan reruntuhan. Gua Pindi merupakan gua paling tinggi yang terletak di Kompleks 
Gua Keirim.

Gua lain yang terdapat di lokasi ini adalah Gua Ujan (hujan). Di gua ini terdapat gambar lukisan tera tangan yang sudah sangat tipis, demikian juga goa Té'ét. Goa Té'ét setinggi Liang Téwét, dan mempunyai tera tangan anak-anak. Pada dinding Gua Téét juga digambarkan sejumlah sosok Dayak memegang mandau dan perisai.

Pada sub Kompleks Gua Tebor terdapat Gua Kebobo (yang kemudian diganti namanya menjadi Gua Akim), Gua Jon, Gua Fosil dan Gua Unak. Gua Fosil adalah satu dari sedikit gua yang menghadap ke utara, dan letaknya persis di ujung Batu Gergaji. Gua ini diberi nama fosil, karena di dindingnya terdapat fosil-fosil cangkang kerang. Gambar yang ada di gua ini adalah gambar arang berupa géko. Sedang pada Gua Unak terdapat banyak pecahan tembikar, terketak di dekat Gua Akim (Kebobo). Di halaman gua ini ditemukan pecahan-pecahan tembikar yang mempunyai tiga warna dalam jumlah yang banyak.

Sub kompleks gua-gua Marang terdapatGuaMentis, Gua Kayu Sapung, dan Gua llas Kecil. Gua-guaini setingkat dengan Gua Tengkorak. Semua situs gua di lokasi ini mengandung jejakjejak arkeologis berupa tera tangan, namun sudah sangat tipis dan bias; sedangkan Gua Mentis adalah gua sarang yang mempunyai imaji teratangan di bagian dindingnya. Imaji tera tangan yang terdapat di Gua Kayu Sapung digambar di dinding yang telah mempunyai batu alur. Gambar-gambar di gua ini umumnya berupa tera-tangan anak-anak. Gua llas Kecil merupakan gua yang tinggalan arkeologis berupa pecahan-pecahan tembikar yang sangat melimpah, sebuah temuan tembikar didapatkan dalam keadaan nyaris utuh. Selain itu, di bagian atap/ plafon gua ini juga ditemukan dua buah gambar tera tangan dewasa.

Sub kompleks Tebo masih menyisakan situs Liang Tebo, Liang Wanadri, dan Liang Sahak yang semuanya mempunyai tera-tangan. Liang Wanadri adalah goa bergambar di dekat gua Jupri yang ditemukan tahun 2006. Liang Tebo adalah liang yang besar, penggalian berhasil menemukan alat gerus untuk hematit. Liang Wanadri merupakan liang kecil, kurang lebih satu jam jalan dari tegalan karst Gergaji ke arah timur. Liang Wanadri mempunyai sedikitnya delapan tera tangan yang sudah sangat pias, dan sebuah objek yang tak terdefinisi.

\section{Karya Seni Pertama Homo Sapiens}

Persebaran seni cadas (rock art) untuk menyebut budaya lukisan dinding, goresan atau pahatan di dinding gua, ceruk atau tebing di Indonesia meliputi antara lain Sulawesi Selatan, Sulawesi Tenggara, Kepulauan Maluku, dan Papua Barat. Seni cadas yang terdapat di Sulawesi Selatan dan Sulawesi Tenggara merupakan situssitus arkeologi yang paling banyak diminati oleh para peneliti dalam dan luar negeri. Pertanggalan mutakhir yang dirilis oleh tim Australia dan Indonesia (2014) bahwa ditemukan data umur tertua dari pengambilan sampel di gua-gua Maros pada angka 40000 tahun sebelum masehi.

Sementara Roder yang meneliti di wilayah Papua Barat, menjelaskan bahwa lukisan dinding di Papua mempunyai umur sekitar 1000 tahun yang lalu. Seni gambar cadas pada gua-gua di semenanjung pegunungan karst Mangkalihat-Sangkulirang di Kabupaten Kutai, Kalimantan Timur mempunyai umur sekitar $11750 \pm 50$ - $5160 \pm 90$ tahun lalu sampai dengan 9800 - 10400 tahun lalu (Chazine dan 
Fage, 2001).

Temuan aneka jenis dan tipe gambar telapak tangan yang tertera di dinding gua/ceruk di kawasan karst Kutai Timur dan ditaksir berusia ribuan tahun yang lalu, memberikan petunjuk untuk pemahaman kita mengenai tradisi simbolik kuno di area tersebut, yang selama ini sangat sedikit sekali diketahui. Termasuk gambar-gambar dinding gua yang berbentuk cap tangan dan binatang besar pada bukit kapur di Sulawesi, begitu pula yang ditemukan di bagian barat Papua seperti di wilayah Kaimana dan Misool Raja Ampat dan beberapa pulau di Asia Tenggara. Lukisan dinding di bagian utara Australia di Provinsi Arnhem Land dan Kimberley juga menampilkan fase seni kuno (bersadarkan urutan superimposition) ditandai dengan gambar cap tangan dan gambar binatang darat dan air, termasuk beragam jenis gambar fauna yang telah punah, yang memiliki persamaan gaya dengan seni di Mangkulirang. Datadata tersebut setidaknya memperkuat dugaan tentang penghunian manusia prasejarah telah berlangsung lama di kawasan Asia Tenggara hingga Australia.

Selama ini, memang terjadi diskusi dan perdebatan dikalangan peneliti mengenai asal dari seni dinding gua (rock art) dari zaman paleolitik. Terutama diskusi dikalangan arkeolog Eropa selama ratusan tahun yang mempertanyakan mengenai perkembangan awal kemunculan gambar dinding, apakah dimulai dari gambar abstrak, tidak berfigur (contoh pola geometris) dan kemudian berkembang menjadi gambar naturalis dengan menampilkan binatang seperti Altamira dan Lascaux, yang berusia \pm 20 ribu tahun yang lalu, dan pada situs Paleolitik akhir di Eropa bagian barat.
Kemudian pendapat ini didorong oleh pengukuran dengan uranium-series dating terhadap 11 gua di Spanyol bagian utara, yang menyimpulkan bahwa gua dengan lukisan dinding tertua di Eropa bukanlah lukisan mengenai figur natural dan lukisan binatang yang lebih awal muncul, tetapi motif lukisan dinding gua tertua di Eropa adalah yang berasal dari El Castillo. Pendapat itu didukung oleh data calcite yang berada di atas gambar 'disk' berwarna merah lalu diperkuat dengan data pertanggalan uranium series pada kisaran usia 408 ribu tahun yang lalu.

\section{Bagaimanapun} hebatnya perdebatan yang terjadi di kalangan para arkeolog dunia tentang dimana dan kapan karya seni gua itu mulai diciptakan manusia, namun hasil penanggalan gambar purba di Maros yang bersebelahan pulau dengan Kalimantan Timur, menunjukkan bahwa seni figurative itu berada pada kisaran 40 ribu tahun yang lalu. Diyakini oleh para peneliti yang bekerja di Maros, bahwa lukisan gua itu merupakan karya seni awal yang dibuat oleh Homo Sapiens. Namun tidak menutup kemungkinan dapat ditemukan peninggalan seni gua selain Sulawesi, maupun di situs guagua Mangkulirang Kutai Timur, atau tempat dan situs gua lainnya di dunia, mungkin saja dapat ditemukan suatu saat di Kalimantan melalui penelitian yang lebih kontinyu dan sistematis pada tahun-tahun mendatang.

\section{Pengelolaan Kawasan Karst Mangkulirang Secara Integratif}

Dalam rangka risiasi
pengusulan kawasan $\begin{array}{r}\text { karst } \\ \text { Mangkulirang sebagai warisan cagar }\end{array}$
budaya dunia, maka diperlukan
adanya upaya pengelolaan secara
terpadu dan integratif. Seperti diketahui


bahwa kawasan karst menyimpan banyak misteri sekaligus potensi yang melimpah dan sebagian lainnya belum dapat diteliti, dikelolah, dikembangkan dan dimanfaatkan secara optimal untuk kepentingan pelestarian. Menurut Tjahjono Prasodjo, mengusulkan perlu adanya tindakan nyata (aksi) berupa dialog dan kerjasama antar disiplin dan antar sektoral bagi pengelolaan dan pemanfaatan lingkungan karst (Prasodjo, 2000: 145-147).

Pesan yang $\begin{array}{r}\text { ingin } \\ \text { disampaikannya, bahwa perlunya } \\ \text { dengan }\end{array}$
keterpaduan (intergrated)
menggunakan pendekatan-
pendekatan baru. Bisa memakai
pendekatan partisipatoris dengan
cara melibatkan seluruh unsur
(komponen) dan potensi masyarakat
dalam mengelolah dan memanfaatkan
sumberdaya budaya dan alam karst
itu. Dapat juga menggunakan gagasan
Otto Soemarwoto dengan paradigma
Atur-Diri-Sendiri (ADS), yaitu
memberikan peran lebih besar pada
masyarakat dan meminimalkan peran
pengawasan pemerintah terhadap
persoalan sumberdaya alam tersebut.

Pendekatan yang sudah lazim digunakan untuk situs-situs arkeologi skala kawasan yaitu melalui pendekatan Culture Resource Management (CRM), adalah suatu usaha untuk pengelolaan suatu sumberdaya budaya dalam rangka pemanfaatan dan pelestarian. Warisan budaya dalam bentuk situs, artefak yang terdapat di dalam kawasan karst bukan semata kepentingan arkeologi ataupun purbakala, tetapi banyak pihak terkait dalam pemanfaatan potensi karst, dengan kepentingan yang berbeda pula (Layto; 1989, dalam Tanudirjo, 1998).

Berdasarkan kerangka pikir tersebut, maka CRM harus dipandang sebagai upaya pengelolaan warisan budaya secara bijak dengan mempertimbangkan kepentingan banyak pihak yang saling bertentangan. Sehingga CRM berkiblat sebagai upaya mencari jalan keluar terbaik agar kepentingan berbagai pihak sebanyak mungkin dapat terakomodasi.

Pendekatan lain yang mulai dikembangkan dewasa ini yaitu "Geopark". Pendekatan ini sifatnya inovatif terhadap daerah yang berkarakteristik seperti yang dimiliki kawasan karst Mangkulirang dengan bentang alam yang luas. Geopark dapat dipahami melalui arti, fungsi dan implementasinya sebagai komponen yang berkaitan dengan bumi. Setidaknya, geopark memiliki tiga pengertian dasar, yaitu:

1. Geopark adalah kawasan yang memiliki arti sebagai suatu warisan geologi, dan menjadi tempat implementasi strategi pengembangan ekonomi berkelanjutan yang dilakukan melalui struktur menejemen yang baik dan realistis.

2. Geopark berimplementasi memberi peluang bagi penciptaan lapangan pekerjaan untuk masyarakat setempat dalam hal memperoleh keuntungan ekonomi secara nyata; biasanya melalui industri pariwisata yang berkelanjutan.

3.Di dalam kerangka geopark, objek warisan geologi dan pengetahuan geologi berbagi dengan masyarakat umum. Unsur geologi dan bentangalam berhubungan dengan aspek lingkungan alam dan budaya. 


\section{PENUTUP}

Suatu kawasan Geopark merupakan sebuah kawasan yang berisi aneka jenis unsur geologi sebagai warisan alam. Di kawasan itu dapat diimplementasikan dan diaplikasikan aneka strategi pengembangan wilayah, yang dalam hal ini promosinya harus didukung oleh program pemerintah. Sebagai kawasan, geopark harus memiliki batas yang tegas dan nyata. Luas permukaan geopark-pun harus cukup, dalam artian dapat mendukung penerapan kegiatan rencana aksi pengembangannya.
Apapun pilihan pendekatan yang diputuskan untuk pelestarian cagar budaya yang tersimpan dalam kawasan karst seperti Mangkulirang, maka diperlukan koordinasi antar semua pihak. Oleh sebab itu ide dan gagasan ini perlu didukung sepenuhnya untuk ditindak lanjuti dengan memperhatikan hasil-hasil penelitian dan kajian kebudayaan yang pernah dilakukan di Kawasan karst Mangkulirang, Kutai Timur. 


\section{DAFTAR PUSTAKA}

Bappeda. 2007. Laporan Akhir Penyusunan Neraca Sumber Daya Alam Sektor Air dan Pertambangan Kabupaten Kutai Timur, Provinsi Kalimantan Timur. BAPPEDA Pemerintah Kabupaten Kutai Timur

Bellwood, Peter. 1985. Prehistory of the Indo-Malaysian Archipelago. Academic Press Australia.

Chazine, J. M., Luc-H. Fage dan Pindi Setiawan. 2001. The Ornate Caves of Kalimantan, Le-Kalimanthrope, Pluridisciplinary Research Group Upon Kalimantan. Belum diterbitkan.

Jatmiko, Nasrudin, dan Bambang Sugiyanto. 2004. "Eksplorasi Situs Gua dan Ceruk Hunian Prasejarah di Pegunungan Marang, Kabupaten Kutai Timur, Kalimantan Timur". LPA Bidang Prasejarah. Kerjasama Penelitian Asdep Urusan Arkenas dengan Credo-CNRS, Maison Asie Pacifique, Marseille France, tidak diterbitkan.

Nasrudin. 2003. "Potensi Situs Gua-gua Hunian dan Temuan Tanda Tangan Prasejarah di Kawasan Pegunungan Marang, Kalimantan Timur". LPA Bidang Prasejarah: Kerjasama Penelitian CREDO Asie-Pacifique dengan Asdep Urusan Arkenas Jakarta. Tidak diterbitkan.

Nasrudin. 2004. "Temuan Tanda Tangan dan Potensi Situs Gua-Gua Hunian di Kawasan Pegunungan Marang, Kalimantan Timur". Kalpataru, Majalah Arkeologi No. 17. Asisten Deputi Urusan Arkeologi Nasional Jakarta.

Prasetyo, Bagyo. 1997. “Gambar Cadas di Kalimantan Barat dan Kalimantan Timur: Indikasi Sebaran di Kawasan Indonesia Bagian Barat" dalam Naditira Widya No. 02/1997, Buletin Arkeologi Balai Arkeologi Banjarmasin. HIm. 44-51.

Prasetyo, Bagyo dan E. A. Kosasih. 1995. "Survei Gua-Gua di Pegunungan Muller, Kecamatan Sangkulirang, Kabupaten Kutai, Provinsi Kalimantan Timur". LPA Balar Banjarmasin, tidak diterbitkan.

Prasodjo, Tjahjono 2000. "Pendekatan Partisipatoris dalam Pengelolaan Sumberdaya Arkeologis dan Kemungkinan Penerapannya di Kawasan Arkeologis Gunungkidul". Berkala Arkeologi. Tahun XX, No. 1/Mei, Balai Arkeologi, Yogyakarta. HIm. 145-147.

Tanudirjo, Daud Aris. 1998. "CRM sebagai Manajemen Konflik". Artefak. No. 19/ Februari 1998. HIm. 14-18. 